Running title - Wet \& Dry contrasts in carbon resources on a tropical floodplain

\title{
Seasonal contrasts in carbon resources and ecological processes on a tropical floodplain.
}

\author{
N.E. Pettit ${ }^{1 *}$, P. Bayliss ${ }^{2}$, P.M. Davies ${ }^{1}$, S.K. Hamilton ${ }^{3}$, D.M. Warfe ${ }^{4}$, S.E. Bunn ${ }^{5}$ \& M.M. \\ Douglas $^{4}$ \\ ${ }^{1}$ Centre for Excellence in Natural Resource Management, University of Western Australia, \\ Australia; ${ }^{2}$ CSIRO, Marine and Atmospheric Research, Brisbane, Australia; ${ }^{3}$ Kellogg Biological \\ Station, Michigan State University, USA ${ }^{4}$ Tropical Rivers and Coastal Knowledge, Charles \\ Darwin University; ${ }^{5}$ Australian Rivers Institute, Griffith University, Brisbane, Australia.
}

\section{Summary}

1. Globally, tropical floodplains are highly productive ecosystems. This is largely due to predictable seasonal rains providing replenishing floodwaters that stimulate nutrient turnover which, in turn, substantially boosts both primary and secondary productivity. This is associated with concomitant shifts in the types of primary producers and associated food webs.

2. The Magela Creek floodplain on Kakadu National Park in northern Australia is one of the most studied tropical freshwater ecosystems in Australia, and provides an opportunity to collate and examine information on organic carbon sources and pathways through food webs to gain a fundamental understanding of how these systems may function.

3. We reviewed biophysical information published since the early 1980 s to construct an assessment of the carbon resources for the channel and floodplain.

4. We conclude that macrophytes, largely in the form of grasses and aquatic plants, produce the greatest above-ground biomass on the Magela Creek floodplain. Although macrophytes provide suitable substrata for the attachment of epiphytes, they do not appear to be an important carbon source for aquatic consumers themselves. Nevertheless, macrophytes do provide critical seasonal food and habitat structure for other producers and consumers on the floodplain, such as the abundant magpie geese.

5. We developed a generalised conceptual food web and carbon budget contrasting the "wet" and "dry" seasons for the Magela Creek system, as a representative of tropical seasonal floodplain systems. 
Running title - Wet \& Dry contrasts in carbon resources on a tropical floodplain

6. Our conceptual model of tropical floodplains indicates that knowledge of the seasonal and spatial links and exchanges between the floodplain and the river is critical in understanding ecosystem function.

Keywords: aquatic food webs, wet-dry tropics, productivity, sources, consumers, connectivity.

*Corresponding author neil.pettit@uwa.edu.au

\section{Introduction}

Tropical floodplains are highly productive ecosystems of global importance to both wildlife and people. They are dominated by seasonal flooding that results in the recurrent deposition of nutrient-rich sediment (McClain \& Richey, 1996; Junk \& Wantzen, 2004) and the replenishment of water supplies that, together, substantially boost primary productivity (Winemiller, 2004;

Davies, Bunn, \& Hamilton, 2008). According to the Flood-Pulse Concept (Junk, Bayley \& Sparks, 1989; Tockner, Malard \& Ward, 2000), seasonal inundation and subsequent drainage are the primary drivers of ecological processes in large floodplain rivers, particularly when the flood pulse is of relatively long duration (Junk \& Welcomme, 1990). In floodplain rivers, a large proportion of the primary productivity that subsequently supports consumers occurs outside the main channel (Junk et al., 1989; Tockner et al., 2000). This typifies many floodplain rivers in the tropics, where seasonal changes in water levels are associated with a dramatic increase in aquatic primary productivity and a corresponding shift in the nature of the dominant primary producers, from algae largely confined to the river channel and isolated water bodies in the dry season, to emergent aquatic macrophytes during floodplain inundation in the wet season (Finlayson, Cowie \& Bailey, 1990a; Finlayson, Cowie \& Bailey, 1993; Douglas, Bunn \& Davies, 2005).

In northern Australia, tropical floodplain rivers are characterised by extreme contrasts between the wet and dry seasons. The pattern of flooding in the wet season is the main driver of productivity on the floodplain and rates of primary production typically show high levels of 
spatial and temporal heterogeneity (Davies et al., 2008). Flood conditions are usually associated with increased nutrient availability and higher aquatic primary production (Junk \& Piedade, 1997) and secondary production including fish (Winemiller, 1996; Winemiller, 2004). Flooding can also lead to an increase in allochthonous carbon inputs, the importance of which to floodplain food webs has been a subject of debate (Zeug \& Winemiller, 2008). How much allochthonous carbon is transferred into the main channel from the floodplain during or following floods is not well understood (Hamilton, Lewis \& Sippel, 1992).

Primary production provides the energy that fuels aquatic food webs but, unlike lentic systems, rivers are generally open systems where carbon and nutrients are "imported", often from the riparian zone (Bunn, Davies \& Mosisch, 1999). The quality of the autotrophic food source is important in aquatic systems and many studies have pointed to the dominant role of algae in river food webs over other sources of carbon such as $\mathrm{C}_{4}$ macrophytes (Hamilton et al., 1992; Thorp \& Delong, 1994; Bunn, Davies \& Kellaway, 1997; Martinelli et al., 1999; Bunn et al., 2005). Although macrophyte production can be very high during the period of floodplain inundation (Junk et al., 1989; Piedade, Junk \& Long, 1991; Finlayson, 1991), only a small fraction of this can be actually consumed, as the coarse particulate matter derived from macrophytes is evidently of poor nutritional value compared to algal organic matter (Hamilton et al., 1992; Bunn et al., 1997; Lewis et al., 2001). Plant detritus on the floodplain will also be broken down via the photochemical effects of solar radiation (Anesio, Tranvik \& Graneli, 1999; Austin \& Vivanco, 2006). This is likely to be particularly important in tropical savanna regions. Fire can also be an important "consumer" of macrophyte biomass on the floodplain (Edwards et al., 2003), as are termites (Salick, Herrera \& Jordan, 1983). However, the fate of this large source of carbon produced by macrophytes on tropical floodplains during the wet season remains largely unknown.

Tropical floodplains are found throughout the northern third of the Australian continent, which is predominantly savanna terrain. Although many areas have been modified by feral animals such as pigs (Sus scrofa), domestic cattle (Bos taurus, B. indicus) and water buffalo (Bubalus bubalis), as well as alien plants such as mimosa (Mimosa pigra) and para grass (Urochloa mutica), they retain their natural hydrological regimes and have seen little large-scale alteration (Stein, Stein \& 
Nix, 2002; Douglas et al., 2005). In Kakadu National Park, 250 km east of Darwin, Australia, there have been numerous environmental studies related to monitoring the impacts of uranium mining on the Magela Creek system within the Park (Gardner, Finlayson \& Pidgeon, 2002). The majority of these studies have focussed on describing the environment and biota, with less attention paid to understanding fundamental ecological processes (Finlayson, 2005), or the cultural and livelihood values for indigenous communities (Jackson, Storrs \& Morrison, 2005). This article uses the available information from the Magela Creek system as a case study, and combines it with data on similar systems from other tropical regions to present a generalised account of carbon resources supporting tropical river/floodplain ecosystems. We address the following questions: what are the ecological functions driving food webs in wet-dry tropical floodplains; and what information is required to improve our knowledge of these ecologically and culturally important tropical ecosystems?

\section{Methods}

\section{Study Site}

This study focuses on information collected in Kakadu National Park in the wet-dry tropics of northern Australia, and specifically on the floodplain of Magela Creek, a seasonally flowing tributary of the East Alligator River, Northern Territory (Fig. 1). Magela Creek arises from sandstone plateau country in the western part of Arnhem Land before flowing across the lowland plains which cover most of Kakadu. Here the creek distributes water in an expansive clay-based floodplain system that covers approximately $200 \mathrm{~km}^{2}$ of the $1600 \mathrm{~km}^{2}$ catchment (Hart, Ottaway $\&$ Noller, 1987a). The floodplain soils of silt and clay have built up through deposition in wet season flooding and these alluvial soils are mostly relatively shallow and are underlain by gleyed marine sediments (Wasson, 1992). The Alligator Rivers Region (Fig. 1), which encompasses the study area, is characterised by a monsoonal climate with two distinct seasons, "wet" and "dry". The wet season starts November-December and usually lasts for three to four months; however, this can vary from year to year (Finlayson et al., 1990a). 
Running title - Wet \& Dry contrasts in carbon resources on a tropical floodplain

Vegetation communities on the lowlands and floodplain are related to micro-topography and therefore to water depth during the wet season (Bowman \& Wilson, 1986; Finlayson, Cowie \& Bailey, 1990b; Finlayson, 2005). Common vegetation includes paperbark (Melaleuca spp.) forests, open perennial and annual swamps, billabongs and grass/sedge herbfields (Williams, 1979). The widespread aquatic grassland communities occupy around $40 \%$ of the floodplains (Finlayson et al., 1993), with Melaleuca spp. forests or woodlands covering around 30 - 40\% (Finlayson, Bailey \& Cowie, 1989).

\section{Data collection}

Biomass and productivity values for the different functional groups were sourced from the large number of published and unpublished reports from over 30 years of environmental studies undertaken on the floodplain of Magela Creek and surrounding aquatic systems. The majority of the unpublished reports can be viewed via the website of the Supervising Scientist Division of the Australian Government Department of the Environment, Water, Heritage and the Arts (http://www.environment.gov.au/ssd/index.html). Where there were gaps in these data, estimates were obtained from published studies on tropical floodplain environments from other regions of the world. Data given as biomass per unit area were scaled up for the total floodplain area (200 $\mathrm{km}^{2}$ ) to give an estimate of carbon for the entire floodplain, expressed as kilogram per hectare. Similarly, data expressed as biomass per unit time were scaled up for the wet season, the dry season, or a combined annual amount. This provided a common "currency" allowing comparison between the contributions of different functional groups to floodplain carbon resources between seasons. An estimate of total surface area and volume of water in billabongs on the Magela Creek floodplain were calculated from dimensions (length, width, depth) given for each waterhole in Bishop et al., (1990).

\section{Magela Creek hydrology}

Flow data for Magela Creek were from a gauging site (GS-8210009) just before the creek flows out onto the floodplain and rainfall data was from the nearby town site of Jabiru. There is high consistency in wet season rainfall and therefore creek flow, but the timing of the commencement and cessation of flows and in particular the magnitude of flows can be highly variable from year 
Running title - Wet \& Dry contrasts in carbon resources on a tropical floodplain

to year (Fig. 2). The long-term mean for total wet season flows in the Magela Creek is 359,000 ML with a coefficient of variation of 0.49 .

The start of the wet season in the Alligator Rivers Region commences around early November with intermittent rain storms saturating the soils and, as more consistent rain occurs, water collects in the creeks that then begin to flow (Hart et al., 1987a). Once the creeks and rivers are full the freshwater moves out across the floodplains and can cover them to a depth of several metres (Finlayson, 2005). Flooding occurs once the catchment is saturated and heavy falls of rain later in the season generate more widespread flooding and discharge than equivalent flows earlier in the season (Finlayson, 2005). An area of about $200 \mathrm{~km}^{2}$ of floodplain is flooded in most years and the extensive areas of aquatic grasses and sedges on the floodplain are generally flooded for three-six months with some low lying swamps flooded for more than six months of the year (Hart \& MacGregor, 1980). By early April, rain becomes intermittent and then stops altogether and freshwater flow in the creeks and rivers ceases within a few months of the end of the rains. From mid-April to mid-September no rain falls and the creeks dry up and the floodplain slowly dries out, except for a few permanent swamps and billabongs (Finlayson et al., 1990a). Total flow volume for the 1982-3 wet season (192300 ML), when several of the studies

reported here were undertaken, was only $53 \%$ of the long term average for Magela Creek (Fig. 2). In addition to this, the commencement of the wet season was later than usual with initial flows occurring in late December 1982 instead of the usual late November or early December (Hart et al., 1987a).

\section{Water quality and material budget}

Data for water quality and material budgets are taken from a study on the Magela Creek in the 1982-3 wet season (Hart et al., 1987a,b). Samples were collected from eight locations to collect water flowing in Magela Creek and entering the floodplain, particularly at the rising stage of the hydrograph when material and nutrient concentrations would be greatest. Organic matter in the sediments of seven billabongs on Magela Creek floodplain was measured at the end of the dry season 1977 (Thomas, Davies \& Hart, 1981). Total organic carbon concentrations in the waters for billabongs of Magela Creek where sampled in December 1977 (Hart \& McGregor, 1980). 
Running title - Wet \& Dry contrasts in carbon resources on a tropical floodplain

\section{Aquatic microorganisms}

As there are no data for biomass or productivity of microorganisms in the Magela Creek, figures for microbial production given by Castillo (2000) on the Orinoco floodplain in South America were extrapolated for the area of Magela Creek floodplain ( 200 km²). Castillo (2000) sampled two floodplain lagoons and two main river sites on the Autana River in Venezuela between 19971998. Bacterial production was estimated from water samples by the rate of incorporation of tritiated leucine into protein (Kirchman 1993; cited in Castillo 2000).

\section{Floodplain grasses}

Estimates of the productivity of the major grass species growing on the Magela Creek floodplain were made from biomass samples taken at four-weekly intervals from October 1983 to February 1985 (Finlayson, 1991) and also from biomass samples of these grasses measured in the dry season 1999 (Douglas and O'Connor, 2004). The proportions of the floodplain occupied by these major grass species are: 15\% for Hymenachne acutigluma, 14\% for Pseudoraphis spinescens and 12\% for Oryza meridionalis (Finlayson et al., 1993).

\section{Woody plants}

Tree density and biomass were measured on the floodplain in October 1983 (Finlayson et al., 1993). As an indicator of the short-term productivity, monthly litter fall was measured in the Melaleuca forest on the Magela floodplain from September 1983 to September 1985 (Finlayson et al., 1988; Finlayson et al., 1993).

\section{Plant litter}

Using the annual biomass of litter fall from the canopy of Melaleuca spp. trees on the Magela Creek floodplain (see above), combined with the dry season biomass of grass (see above), and allowing for $30 \%$ removal of detritus in floodplain fires (Edwards et al., 2003), we calculated an estimate of the annual contribution of detrital carbon from vascular plants to the total floodplain.

\section{Algae}

Chlorophyll $a$ measurements, as an estimate of algae biomass in the water column, were taken in Magela Ck billabongs at the end of dry season 1977 and during the wet season 1978 (Hart \& 
Running title - Wet \& Dry contrasts in carbon resources on a tropical floodplain

MacGregor). Phytoplankton net productivity was measured using light/dark bottle techniques (sensu Odum, 1957) at four sites on the floodplain in the 2000 wet season (P. Davies, unpublished data). Biomass of diatoms attached to aquatic macrophytes was measured using diatom samplers on the floodplain during the wet seasons of 1980 to 1982 (McBride, 1983).

\section{Aquatic macroinvertebrates}

Aquatic macroinvertebrates on the Magela Creek floodplain were sampled with sweep nets (epiphytes on aquatic grasses) and suction samplers (benthic habitat), used to quantify abundance across four sites in the mid to late wet season of 1998 and 1999 (Douglas \& O'Connor, 2003). The abundance and biomass of benthic macroinvertebrates were sampled in $0.25 \mathrm{~m}^{2}$ quadrats also at monthly intervals (March 1981 to April 1982) from three sites on four Magela Creek billabongs in littoral and stream riffle areas (Marchant, 1982; Outridge, 1988).

\section{Fish}

Comprehensive seasonal sampling of fish in the Magela Creek systems was undertaken from 1978 to 1981 with species collected from all main habitat types (main channel waterbodies; lowland backflow billabongs; lowland sandy creeks, corridor waterbodies; and floodplain billabongs; Bishop, 1987). Two standard netting techniques were used, designed to provide a representative sample from a site: multi-mesh size gill netting and seine netting (Bishop et al., 1990). To estimate fish biomass for the entire area of the floodplain, we assumed that the majority of fish in the system were concentrated at the billabong and creek sites sampled (Bishop et al., 1990) and that sampling years 1978-1979 were typical (annual rainfall 1433mm, long term average 1400mm; Fig. 2).

\section{Turtles}

The relative abundances and density of freshwater turtles along the Magela Creek and billabongs were estimated from sampling 12 sites surveyed in the early wet season 1982 (Legler 1982). Based on these observations and the average size of each species, an estimate of turtle biomass for the Magela Creek floodplain was calculated.

\section{File Snakes}


File snakes (Acrochordus arafurae, Acrochordidae) are an abundant vertebrate predator found in billabongs on the Magela Creek floodplain (Shine, 1986). The population size of file snakes was estimated in seven billabongs by standard mark and re-capture techniques using fyke nets (Shine, 1986; Houston \& Shine, 1994). Estimates of the contribution of files snakes to annual biomass on the floodplain were based on population densities of $A$. arafurae in billabongs and average body size measurements from seven surveys in the late dry season and two wet season sampling events, from 1985 to 1988 (Houston \& Shine, 1993, 1994).

\section{Waterbirds}

Estimates of waterbird numbers on the floodplain for the dry and wet seasons were taken from monthly aerial surveys along fixed transects from June 1981 to August 1984 (Morton et al., 1990a,b; 1993a,b) and in August, September and October 1990-92 (Dostine \& Skeat, 1993). The wet biomass of waterbirds was estimated from the average adult male and female body weight of each species.

\section{Crocodiles}

In the floodplain sections of northern Australian rivers, saltwater crocodiles (Crocodylus porosus) tend to greatly outnumber freshwater crocodiles (C. johnstoni) mainly due to competitive exclusion (Webb, Manolis \& Sack, 1983) and, hence, in this paper we focussed on $C$. porosus. Spotlight surveys were undertaken in June and August 1983 on Magela Creek (Jenkins $\&$ Forbes, 1985). In these surveys, marked seasonal variations occurred in the abundance of crocodiles that are attributed to movements between the river and adjacent freshwater swamps. Crocodylus porosus males vary in average length between $3-5 \mathrm{~m}$ and weigh around 400-700 kg, and females vary in average length between $2-3.5 \mathrm{~m}$ and weigh around $150-300 \mathrm{~kg}$ (Webb et al., 1978). We used these measurements to estimate average non-hatchling crocodile biomass on the floodplain.

\section{Results}


A summary of the estimated annual carbon contribution for the major sources and consumers on the Magela Creek floodplain is presented in Table 1 and highlights the dominance of macrophytes and leaf litter as carbon sources to floodplain systems. These figures are based on the numerous studies on the Magela Creek and are discussed in more detail in the sections below.

\section{Water quality and material budgets}

Water quality for the Magela Creek in the 1982-1983 wet season showed high variation depending on climatic and disturbance conditions within the catchment, highlighting the differences between first flows and flood flows (Table 2). First flush flows were quite acidic (pH $4-5$ ), with high conductivity and sulphate concentrations. There were also high concentrations of total $\mathrm{P}$ and other nutrients in the first flows of the season while available $\mathrm{N}$ was much greater in subsequent wet season flows. The floodplain was generally a net source of the major ions and a net sink for nutrients ( $\mathrm{N}$ and $\mathrm{P}$ ) and suspended matter (Table 2). During the 1982-1983 wet season on Magela Creek, the input from runoff for the whole catchment was $5400( \pm 5800)$ tonnes of total suspended sediment (TSS) and the output was $1700 \mathrm{t}( \pm 540)$, leaving $3700 \mathrm{t}$ $( \pm 5900)$ deposited on the floodplain. Unfortunately, little data on DOM or POM for the Magela Creek floodplain is available. Organic matter in the sediments of the billabongs on Magela Creek varied between 0.1 to $20 \%$, with an average of $9.5 \%$. Total organic carbon concentrations in the

waters for billabongs on Magela Creek in December 1977 averaged $\left( \pm\right.$ SE) $6.4 \pm 2 \mathrm{mg} \mathrm{L}^{-1}$. Water temperature in streams and billabongs varied little between seasons and varied between 28 and $32^{\circ} \mathrm{C}$, with stratification seen only in the deepest billabongs where temperature varied between $30.5^{\circ} \mathrm{C}$ at the surface to $25.7^{\circ} \mathrm{C}$ on the bottom (Bishop et al., 1990).

\section{Aquatic microorganisms}

No studies of aquatic microorganisms (bacteria and fungi) on Magela Creek or nearby floodplains have been published. Bacterial production on the Orinoco River, South America (Castillo, 2000; Castillo, Kling \& Allan, 2003) was 0.62-1.03 $\mu \mathrm{g} \mathrm{C} \mathrm{L}^{-1} \mathrm{~h}^{-1}$ in floodplain lakes and 0.17-0.19 $\mu \mathrm{g} \mathrm{C} \mathrm{L}^{-1} \mathrm{~h}^{-1}$ in the main-channel during the period of low water, while during the period of high water, river and lake sites showed similar low levels $\left(0.04 \mu \mathrm{g} \mathrm{C} \mathrm{L}^{-1} \mathrm{~h}^{-1}\right)$. We used these figures to estimate annual microbial production for the Magela Creek floodplain (Table 1). 


\section{Floodplain grasses}

The widespread aquatic grasslands that cover the Magela Creek floodplain are highly productive,

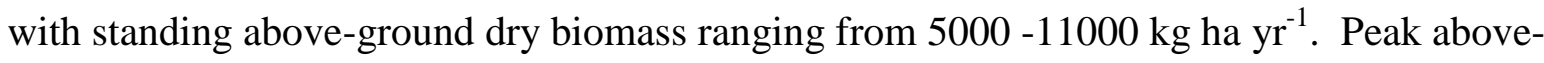
ground biomass coincides with the end of the wet season, with receding water levels. Peak biomass for major grass species on the floodplain was between $14100-44300 \mathrm{~kg} \mathrm{ha}^{-1}$ for Hymenachne acutigluma, 5100 - $11700 \mathrm{~kg} \mathrm{ha}^{-1}$ for Oryza meridionalis, $16700 \mathrm{~kg} \mathrm{ha}^{-1}$ for Psuedorhaphis spinescens and $41200 \mathrm{~kg} \mathrm{ha}^{-1}$ for the introduced para grass (Urochloa mutica). The carbon to nitrogen ratios for the grasses on the floodplain ranged from 33 - 37 for Hymenachne acutigluma and 47 - 67 for Urochloa mutica (Douglas et al., 2002). Higher biomass is generally apparent in grass communities occurring around low-lying channels and billabongs during the dry season, but varies greatly on the floodplain, both spatially and temporally, depending on climatic conditions and the degree of flooding. Annual biomass of carbon from these grasses is around 45 to $50 \%$ (excluding trees) of the total carbon on the floodplain (Table 1).

\section{Woody plants}

Calculated average $( \pm$ SE) tree biomass for the main tree species on the Magela floodplain was $775 \pm 1.6 \mathrm{~kg}$ for Melaleuca viridiflora and $1009 \pm 1.6 \mathrm{~kg}$ for Melaleuca cajaputi. An average density of 294 trees ha $^{-1}$ with the trees occupying $30 \%$ of the floodplain gives a total standing aboveground dry biomass of about $45000 \pm 3000 \mathrm{~kg} \mathrm{ha}^{-1}$ which is $40-50 \%$ of the carbon on the floodplain (Table 1). The majority of this carbon is stored in the woody material of stems and branches of trees and only turned over after long time spans (i.e. decades). However, short timescale turnover of the productivity from these trees can be measured as litter fall (Table 1, and see below). For Melaleuca species litter C:N ratios are likely to be in the order of 25 to 60 (Greenway, 1994).

\section{Plant litter}

The extensive grasslands on the Magela Creek floodplain contribute large amounts of detritus to the aquatic system. Litter from Melaleuca trees on the floodplain also contributes detritus to the aquatic system but is likely to decompose at a much slower rate than grass material. The annual biomass of litter fall from the canopy of Melaleuca spp. trees on the Magela Creek floodplain 
Running title - Wet \& Dry contrasts in carbon resources on a tropical floodplain

was combined with dry season biomass of grass to give an indicative contribution of detrital carbon from vascular plant sources to the total floodplain (Table 1).

\section{Algae}

During the wet season, the high flushing rate and subsequent export of phytoplankton resulted in low phytoplankton productivity in the billabongs, while dry season productivity increased but varied substantially according to water quality conditions including turbidity, light, nutrients and chemistry of individual billabongs. Chlorophyll $a$ concentrations in the Magela Creek billabongs showed peak values at the end of the dry season $\left(19 \mathrm{~g} \mathrm{~m}^{-3}\right)$ which reduced to less than $8 \mathrm{~g} \mathrm{~m}^{-3}$ after the billabong had become connected during the wet season. For comparison these figures were converted to $\mathrm{kg} \mathrm{C}$ per ha of surface water of the floodplain (Table 1). We measured net production rates of $1.1 \mathrm{~g} \mathrm{C} \mathrm{m}^{-3} \mathrm{day}^{-1}$ in the 2000 wet season on the Magela Creek floodplain (P. Davies, unpublished data). This measurement of productivity would translate to around $990 \mathrm{~kg}$ ha $\mathrm{yr}^{-1}$ which is much higher than phytoplankton biomass estimates (Table 1), indicating the high turnover of algal biomass on the floodplain. Diatoms are usually restricted to the littoral areas of billabongs during the dry season but large diatom biomass was found on the floodplain as epiphytes on the abundant macrophytes at the time of highest production during the late wet season (Table 1). From these figures annual algal biomass contributes around $4-6 \%$ of carbon on the floodplain.

\section{Aquatic macroinvertebrates}

Studies of aquatic macroinvertebrates on the Magela Creek system showed the greatest numbers of taxa and individuals were collected during the late wet season and early dry season in the littoral zones of shallow billabongs (Marchant, 1982). Abundance of aquatic macroinvertebrates on the floodplain in the mid to late-wet season over two years and across four sites averaged 2880 to 17287 individuals per sample within the epiphytes and 1952 to 3210 individuals per sample in the benthic habitat. In the sediments of four Magela Creek billabongs and stream riffles of Magela Creek, annual total standing biomass of invertebrates was dominated by the freshwater mussel Velesunio angasi (Hyriidae), representing $>98 \%$ of the biomass (Outridge, 1988). At all sites abundance and standing crop were substantially reduced towards the end of the dry season. Total annual standing crop of benthic invertebrates was $119 \mathrm{~kg} \mathrm{ha}^{-1} \mathrm{yr}^{-1}\left(1.8 \mathrm{~kg} \mathrm{ha}^{-1} \mathrm{yr}^{-1}\right.$ 
Running title - Wet \& Dry contrasts in carbon resources on a tropical floodplain

excluding $V$. angasi) in billabongs. Annual contribution to floodplain carbon by macroinvertebrates is only around $0.03 \%$ of the total (Table 1 ).

\section{Fish}

Highest inter-annual variability in community structure, total abundance and biomass across all sites occurred in the late-dry and early-wet seasons. Major contributing factors to inter-annual variability in fish abundance include the area and depth of water at the end of the wet and dry seasons, time since initial flow, recent history of inundation and abundance and density of aquatic macrophytes. Many fish migrate to the floodplain from dry season refugia (backflow billabongs) during the early wet season (Bishop, 1987). Seasonal variation in fish abundance and biomass varied with habitat and the numbers of fish in backflow billabongs and sandy bed creek channels peaked in the mid-wet season, and were lowest at the end of the dry season. If we assume that the majority of fish in the system are concentrated at these sites and that the sampling years 19781979 are typical (Fig. 2), then fish biomass (dry weight) in the dry season in backflow billabongs was approximately $18-45 \mathrm{~kg} \mathrm{ha}^{-1}$, in corridor billabongs $12-16 \mathrm{~kg} \mathrm{ha}^{-1}$ and in floodplain billabongs 11 - $21 \mathrm{~kg} \mathrm{ha}^{-1}$, meaning fish contribute $0.04-0.09 \%$ of carbon to the floodplain (Table1).

\section{Freshwater turtles}

Average relative density of all turtles along the Magela Creek sites was 0.89 individuals $100 \mathrm{~m}^{-1}$. A total of 51 turtles from five species (Family Chelidae ) were observed at eight Magela Creek sites in the early wet season 1982. This equates to approximately $3.2 \mathrm{~kg} \mathrm{ha}^{-1}$ of turtle biomass for the billabongs of the Magela Creek floodplain (Table 1). This is potentially an overestimation for the whole of the floodplain due to the concentration of animals in billabongs in the dry season.

\section{File snakes}

During the dry season, file snakes (Acrochordus arafurae) are restricted to the main billabongs and estimates of 100 snakes $\mathrm{ha}^{-1}$ have been recorded. This pattern changes in the wet season, with most snakes migrating onto the shallow, inundated floodplain. File snakes averaged 0.725 $\mathrm{kg}$ body mass (based on 4184 snakes, Houston \& Shine, 1993), consequently the biomass per 
hectare at surveyed billabongs was approximately $72.5 \mathrm{~kg} \mathrm{ha}^{-1}$ so that for the whole floodplain this would translate to a contribution of around $0.5 \mathrm{~kg} \mathrm{C} \mathrm{ha}^{-1}$ (Table 1).

\section{Waterbirds}

Seasonal variations in waterbird numbers on the Magela floodplain are due to large numbers of birds moving onto (dry season) and off (wet season) the floodplain. The contrast in numbers between the wet and dry seasons is apparent for most waterbird species with the exception of black-necked storks (Ephippiorhynchus asiaticus) and cormorants (Phalacrocorax spp.), which have generally low numbers on the floodplain (Table 3). Magpie geese (Anseranas semipalmata) are the dominant species on the Magela Creek floodplains and exemplify the dramatic seasonal changes in abundances (Table 3). Magpie geese comprised about $77 \%$ of the total waterbird biomass at the dry season peak (Table 3). Wet season waterbird density was much lower with a total observed density of around $0.62-1.82 \mathrm{ha}^{-1}$, with magpie geese still comprising $76 \%$ of the total (Table 3).

\section{Crocodiles}

Saltwater (C. porosus) are the top predators on the Magela Creek floodplain. Spotlight surveys in June and August 1983 estimated a crocodile density on Magela Creek of between $1.9-5.3 \mathrm{~km}^{-}$

1. These figures yield an estimate of between 85 -238 non-hatchling crocodiles along the $45 \mathrm{~km}$ section of the Magela Creek in which they would be expected to occur, which would give an approximate total weight of $16,530-465,000 \mathrm{~kg}$ of crocodiles on the $200 \mathrm{~km}^{-2}$ floodplain, or 0.8 $-2.5 \mathrm{~kg} \mathrm{ha}^{-1}$ of non-hatchling crocodiles on the Magela Creek floodplain, contributing $0.01 \%$ of the total annual carbon on the floodplain (Table 1). These figures are likely to be a substantial underestimate as surveys only identify the crocodiles present in the accessible channels (Bayliss et al., 1986). Saltwater crocodile numbers have increased considerably in northern Australia since hunting was banned in 1971 (Bayliss, 1987; Parks \& Wildlife Service NT Government, 2004).

\section{Discussion}


Running title - Wet \& Dry contrasts in carbon resources on a tropical floodplain

\section{Carbon fluxes on the floodplain}

Seasonal changes in flow regimes and hydrological connectivity are the principal drivers of tropical aquatic ecosystem function (Lewis, 2008; Douglas et al., 2005). Australian tropical rivers represent an extreme in intra-annual hydrologic variability, with flows always strongly seasonal (McMahon et al., 1991; Petheram, McMahon \& Peel, 2008). This is particularly apparent in some regions of tropical Australia where high inter-annual variability can occur as a consequence of climatic variability and particularly the El Niño-Southern Oscillation (Hamilton \& Gehrke, 2005; Bayliss et al., 2008). The marked seasonality between the wet and dry seasons has a great influence on the distribution and productivity of the flora and fauna on the floodplain (Fig. 3; Douglas et al., 2005). The large hydrologic changes between the wet and dry seasons require radical changes in diet, behaviour and habitat use of animals using the floodplain (Fig. 3). For example, the change from flooded to dry conditions prompts a characteristic shift in animals between habitats such as dusky rats moving from the floodplain in the dry season to terrestrial habitats when the floodplain is flooded in the wet season (Madsen \& Shine, 1996). Similarly, vast populations of magpie geese that congregate on the floodplain in the dry season disperse to other habitats during the wet (Bayliss, 1989; Bayliss \& Yeomans, 1990). Fish experience large changes in habitat conditions between large areas of flooded, highly productive floodplain in the wet season to refugial waterholes with limited space and deteriorating water quality as the dry season proceeds (Fig. 3). Inundation periods on floodplains can bring fish into contact with greater and more varied sources of carbon (Perga, Arfi \& Gerdeaux, 2005) and for some fish inundation provides opportunities for spawning or improving body condition (Winemiller \& Jepsen, 1998).

Dry season fires are also a significant 'consumer' of carbon on the floodplains, with ignition of the drying grass from numerous lighting strikes and from indigenous and non-indigenous burning practices (Bayliss et al., 2006; Fig. 3). Increased fire frequency and intensity reported on Kakadu floodplains, including Magela Creek floodplain, in the late 1980s-early 1990s, is related to the eradication of water buffalo and the subsequent increase in aboveground grass biomass (Gill et al., 2000). This will undoubtedly have other ecological effects on the Magela floodplain. For example, several species of frog and freshwater turtle aestivate in the dry sediments on the floodplain during the dry season and increased fire intensity may increase soil temperatures to levels lethal for these animals. 
This paper summarises the available information on the abundance and productivity of the predominant producers and consumers that occur on the Magela Creek floodplain as a case study or model of how food webs and carbon fluxes function in tropical Australian floodplain systems (Fig. 3). This highlights the many similarities with other tropical regions such as South America and Africa (Lewis et al., 2001; Winemiller, 2004; Davies et al., 2008) including the nature and relative contributions of primary producers to overall ecosystem productivity and the inferred importance of algal production to aquatic food webs (Douglas et al., 2005). Although productivity of macrophytes (principally grasses and sedges) on the Magela floodplain was less than the $80,000 \mathrm{~kg} \mathrm{ha}^{-1}$ measured on the Amazon floodplain for the $\mathrm{C}_{4}$ grass Echinochloa polystachya (Piedade et al., 1991), they were similar to the $4000 \mathrm{~kg} \mathrm{ha}^{-1}$ measured on the Orinoco floodplain (Hamilton \& Lewis, 1987) and high in comparison to other tropical savannas (Grace et al., 2006). In these latter tropical floodplains, primary productivity was therefore dominated by macrophytes. Despite this, several studies have indicated that very little of the carbon from this source directly enters the aquatic food web (Hamilton et al., 1992; Lewis et al., 2000). Although algae are much less conspicuous, high turn-over rates can maintain significant consumer biomass (Table 1, cf. $300 \mathrm{~kg} \mathrm{ha}^{-1}$ for the Orinoco River floodplain (Lewis et al., 2000)). Indeed on the floodplain of the Orinoco River, carbon sources for consumers were mostly algal, despite macrophytes and litter-fall providing $98 \%$ of potentially-available carbon (Lewis et al., 2001). The source of carbon for fish on the central floodplain of the Amazon River, where $\mathrm{C}_{4}$ macrophytes were the greatest primary producer, was mostly from phytoplankton despite this being a minor contributor to overall catchment productivity (Fosberg et al., 1993; Lewis et al., 2001). However, notwithstanding the fact that algae are likely to be a critical basal source for the floodplain food web, biomass and rates of productivity of benthic and epiphytic algae on the floodplain are poorly-known and have rarely been adequately quantified (Davies et al., 2008).

Riparian and floodplain forests provide another source of allochthonous carbon in tropical floodplains. The Magela floodplain forest is dominated by Melaleuca spp. with few other overstorey species (see Cowie, Short \& Osterkamp-Madsen, 2000). Leaves of Melaleuca spp., like those of other Myrtaceae genera, are highly lignified and refractory (Finlayson et al., 1988) and, consequently, are not readily available as a food source for aquatic consumers. Leaves that 
break down quickly are used as food by organisms, and those that persist longer in aquatic environments are often used as habitat or substrate (Stout, 1980). The species-poor overstorey of the Magela floodplain is unlike other floodplain forests, such as the Amazon which has a high diversity of tree species and a variety of leaf types (Junk, 1993), with different decomposition rates providing a mixture of food and habitat sources for organisms (Gonçalves et al., 2006). However, some tree species that occur on the Magela Creek floodplain , including Syzidium spp., Barringtonia acutangula, Ficus spp. and Pandanus aquaticus, have fleshy fruits which may provide a food source for fish (Davis et al., 2010) and other aquatic consumers such as turtles (Legler, 1982). The importance of this may be limited on the Magela floodplain however, compared to the flooded forests of other tropical floodplains such as the Amazon where there are specialist frugivorous fish (Goulding, 1980).

The low relief, resistant rocks and lack of development within the catchment contribute to the low TSS and nutrient levels recorded for Magela Creek compared with other tropical systems (Lewis, 2008) and perhaps are most similar to levels recorded for the nutrient-poor blackwater streams such as the Rio Negro in the Amazon Basin (Lewis, 2008; Davies et al., 2008). Therefore, the Magela Creek floodplain is probably more nutrient-limited and consequently less productive than some other tropical floodplain systems such as the Llanos of the Orinoco in Venezuela and the Pantanal wetland in Brazil (Lewis, 2008). Diversity and abundance of phytoplankton, zooplankton and macroinvertebrates are similar in Magela Creek to values in other tropical floodplain systems (Dudgeon, 1992; Finlayson, 2005; Jacobsen et al., 2008). Although fish productivity is similar in Magela Creek, diversity is much lower than in other tropical regions (Winemiller 2004), in part due to the relatively recent creation of these wetlands (Wasson, 1992). The low nutrients and productivity for Magela floodplain may result in a less complex aquatic food web structure (Douglas et al., 2005) with shorter food chain lengths (e.g. epiphytic algae $>$ bony bream $>$ barramundi $>$ crocodiles). Similarly, river productivity in the Amazon Basin also affects trophic structures with food chain lengths longer in more productive white-water rivers than nutrient- poor blackwaters (Jepsen \& Winemiller, 2002).

\section{Role of macrophytes on the floodplain}


Running title - Wet \& Dry contrasts in carbon resources on a tropical floodplain

Macrophytes on the floodplain have crucial ecological roles in addition to primary production. Particularly in the wet season, macrophytes provide habitat in the form of refugia for aquatic prey animals and cover for aquatic predators. Macrophytes also provide substrates for the growth of epiphytic algae where shading, water depth and turbidity may inhibit the growth of benthic algae. Epiphytic N-fixing algae (e.g., Nostoc spp.), which enhance N sources for algal production in Nlimited systems, characterise the floodplain of the East Alligator River in northern Australia (Douglas et al., 2005; Davies et al., 2008). Recycled macrophyte material is also likely to be an important source of soil nutrients on the floodplain with grass detritus containing substantially higher levels of nutrients $(\mathrm{N}, \mathrm{P}, \mathrm{K})$ than concentrations in the inputs of water from the creek (Finlayson, 1991).

Despite the widespread area of grasslands on the Magela Creek and other northern Australian floodplains, there are no large extant native herbivores to consume this biomass. This is in contrast to floodplain grasslands on other continents where medium to large native herbivores occur, such as hippopotamus (Hippopotamus amphibius) in Africa, capybara (Hydrochoerus hydrochaeris) in South America and moose (Alces alces) in North America. In pre-European times, manatees (Trichechus inunguis) and capybara were much more abundant on the Amazon floodplain, moving onto the floodplain in the wet season to feed on the macrophytes (Junk, 1997). This suggests that on the Amazon floodplain macrophytes have perhaps become a more dominant feature of the floodplain in more recent times. On the Magela Creek floodplain, feral water buffalo have been a major herbivore since their introduction in the early 1800s before an extensive eradication program initiated in 1985 greatly reduced numbers (Bayliss et al., 2006). The cessation of traditional indigenous burning practices on the floodplain in the late dry season, most likely in combination with a substantial reduction of buffalo numbers, has led to an increase in the area of the native grass Hymenachne acutigluma in the wetter areas and the exotic para grass Urochloa mutica in drier areas, where it has replaced native wild rice (Oryza spp.) (Ferdinands, Beggs \& Whitehead, 2005). There is evidence however that this $\mathrm{C}_{4}$ grass is not utilized in the aquatic food web on the floodplain (Bunn et al., 1997; Douglas et al., 2002). Feral pig numbers have increased rapidly since 1985 (corresponding to the decline in buffalo numbers) and they are now widespread consumers of plants, especially Eleocaris dulcis sedges, competing 
Running title - Wet \& Dry contrasts in carbon resources on a tropical floodplain

directly with waterbirds such as magpie geese (Anseranas semipalmata) and brolgas (Grus rubicunda) (Fig.3; Bayliss et al., 2006).

Water birds such as magpie geese consume macrophyte biomass including the tubers of the sedge Eleocharis dulcis and the seeds and probably some leaf and stem material of wild rice (Morton et al., 1990a). Seeds of wild rice are also eaten by granivorous rodents that occupy the margins of the Magela floodplain (Wurm, 1998). Wild rice seeds are also eaten by some herbivorous fish species on the central Amazon River (Forsberg et al., 1993). Possible indirect links of floodplain macrophytes to the aquatic food web could occur via terrestrial insects such as grasshoppers feeding on emergent macrophytes, which may then be eaten by insect predatory fish such as the archer-fish (Toxotes spp.) or rainbow-fish (Melanotaenia spp.). The importance of terrestrial subsides for the maintenance of aquatic ecosystems has been highlighted for riparian areas (Nakano \& Murakami 2001; Baxter, Fausch \& Saunders 2005) and is obviously important on floodplains; however the distinction between terrestrial and aquatic subsidies is not clearly defined.

\section{Conclusions}

The interaction at the terrestrial-aquatic interface in river floodplain systems generally results in high diversity and productivity (Naiman \& Décamps, 1997; Naiman, Décamps \& McClain, 2005). This is due to the interactions between flooding, sediment transport, biotic processes (primary and secondary production and processing of organic matter) and hydrological connection and disconnection as waters inundate and recede from the floodplain (Fig. 3; Tockner et al., 2000; Tockner, Lorang \& Stanford, 2010). Floodplain rivers have always been highly valued environments for people in terms of settlement and exploitation (Ward, 1998; Junk \& Wantzen, 2004; Winemiller, 2004; Jackson et al., 2005) and hence are impacted by multiple stressors (Tockner et al., 2010). Therefore, in the case of tropical floodplain rivers, knowledge of the seasonal and spatial links and exchange between the floodplain and the river is critical. Particular components of this include understanding the dynamics of primary producers such as algae which appear to be a critical basal carbon source in the aquatic food web. We also have little understanding under what conditions and scales, the floodplain is either a source or a sink of organic matter to the river and how the biophysical heterogeneity of floodplains contributes to the 
Running title - Wet \& Dry contrasts in carbon resources on a tropical floodplain

storage, use, regulation and movement of organic matter. In terms of secondary consumers, there is a lack of information on the movement of fish on and off the floodplain, and the utilization of the floodplain for feeding and/or reproduction. Food web effects of fish feeding on the floodplain and maintenance in dry season refugia are currently poorly understood. Other areas that require more information include the effects on food webs and the carbon budget of the feeding and migration patterns of waterbirds, and the effects of feral animals and exotic plants. We also need to understand the importance of littoral areas of waterholes and floodplains in supporting biodiversity and as areas of high inputs of allochthonous and autochthonous organic matter as well as for nutrient cycling (Strayer \& Findlay, 2010).

This paper has provided insights into the ecological functions that drive food webs in tropical floodplain rivers. This ecosystem-function level of understanding is critical for the management of wet-dry tropical floodplains. For example, determining environmental flow requirements for rivers assumes that natural flow regimes and associated hydrological-ecological linkages are well known. This is clearly not the case in tropical floodplain rivers in many regions of the world. Most research on environmental flows has focused on predicting changes in aquatic habitat and then using this to predict likely responses of particular biota. Therefore, assessments of environmental flows need to include fundamental ecosystem processes related to the connectivity between the river and the floodplain, but very few studies have attempted this in tropical regions. We have highlighted the information that is known in this regard and the obvious gaps in our conceptual understanding of these systems, and thereby provided a conceptual framework for future work.

\section{Acknowledgments}

The authors wish to thank R. J. Naiman (University of Washington) and T. Jardine (Griffith University) for constructive comments on previous drafts. Funding for this project was provided by the Tropical Rivers and Coastal Knowledge (TRaCK) research programme which receives major funding for its research through the Australian Government's Commonwealth Environment Research Facilities initiative, the Australian Government's Raising National Water Standards Programme, the Fisheries Research and Development Corporation, and the Queensland Government's Smart State Innovation Fund. 
Running title - Wet \& Dry contrasts in carbon resources on a tropical floodplain

\section{References}

Anesio A.M., Tranvik L.J. \& Graneli W. (1999) Production of inorganic carbon from aquatic macrophytes by solar radiation. Ecology, 80, 1852-1859.

Austin A.T. \& Vivanco L. (2006) Plant litter decomposition in a semi-arid ecosystem controlled by photodegradation. Nature, 442/3, 555-558.

Baxter C.V., Fausch K.D. \& Saunders W.C. (2005) Tangled webs: reciprocal flows of invertebrate prey link streams and riparian zones. Freshwater Biology, 50, 201 - 220.

Bayliss P., Bartolo R. \&van Dam R. (2008) Quantitative ecological risk assessments for the Daly River. In: Ecological risk assessment for Australia's northern tropical rivers. (Eds. R. Bartolo, P. Bayliss and R. van Dam), pp 271-415. Environmental Research Institute of the Supervising Scientist, National Centre for Tropical Wetland Research, Darwin, Australia.

Bayliss P. (1989) The population dynamics of magpie geese in relation to rainfall and density: implications for harvest models in a fluctuation environment. Journal of Applied Ecology, 26, 913-924.

Bayliss, P. (1987) Survey Methods and Monitoring in Relation to Population Management. In: Wildlife Management. Crocodiles and Alligators., (Eds. G. Webb, C. Manolis and P. Whitehead), pp 157-175. Surrey Beatty and Sons Pty Ltd, Sydney, Australia.

Bayliss P. \& Yeomans K.M. (1990) Seasonal distribution and abundance of Magpie Geese Anseranas semipalmata Latham, in the Northern Territory, and their relationship to habitat, 1983-86. Australian Wildlife Research, 17, 15-38.

Bayliss P., Webb G.J.W., Whitehead P.J., Dempsey K. \& Smith A. (1986) Estimating the abundance of saltwater crocodiles, Crocodylus porosus Schneider, in tidal wetlands of the Northern Territory: a mark-recapture experiment to correct spotlight counts to absolute numbers, and the calibration of helicopter and spotlight counts. Australian Wildlife Research, 13, 309-320.

Bayliss P., van Dam R., Boyden J. \& Walden D. (2006) Ecological risk assessment of Magela floodplain to differentiate mining and non-mining impacts. In: ERISS research summary 2004-2005 (Eds. K.G. Evans, J. Rovis-Hermann, A. Webb \& D.R. Jones). Supervising Scientist Report 189, Supervising Scientist, Darwin NT, Australia.

Bishop K.A. (1987) Dynamics of the freshwater fish communities of the Alligator Rivers Region, tropical Northern Australia. PhD thesis, Macquarie University, Sydney, Australia.

Bishop K.A., Allen S.A., Pollard D.A. \& Cook M.G. (1990) Ecological studies on the freshwater fishes of the Alligator Rivers Region, Northern Territory. Volume II Synecology. Research Report 4 (ii), Supervising Scientist for the Alligator Rivers Region, AGPS, Canberra, Australia.

Bowman D.M.J.S. \& Wilson B.A. (1986) Wetland vegetation pattern on the Adelaide River flood plain, Northern Territory, Australia. Proceedings of the Royal Society of Queensland, 97, 6977.

Bunn S.E., Davies P.M. \& Kellaway D.M. (1997) Contributions of sugar cane and invasive pasture grass to the aquatic food web of a tropical lowland stream. Marine and Freshwater Research, 48, 173-179.

Bunn S.E., Davies P.M. \& Mosisch T. (1999) Ecosystem measures of river health and their response to riparian and catchment degradation. Freshwater Biology, 41, 333-345. 
Running title - Wet \& Dry contrasts in carbon resources on a tropical floodplain

Bunn S.E., Balcombe S.R., Davies P.M., Fellows C.S. \& McKenzie-Smith F.J. (2005) Aquatic productivity and food webs of desert river ecosystems. In: Changeable, Changed, Changing: The ecology of desert rivers (Ed. R. Kingsford), pp. 76-99. Cambridge University Press, Cambridge, UK.

Castillo M.M. (2000) Influence of hydrological seasonality on bacterioplankton in two neotropical floodplain lakes. Hydrobiologia, 437, 57-69.

Castillo M.M., Kling G.W. \& Allan J.D. (2003) Bottom-up controls on bacterial production in tropical lowland rivers. Limnology and Oceanography, 48, 1466-1475.

Cowie I.D., Short P.S. \& Osterkamp-Madsen M. (2000) Floodplain flora: A flora of the coastal floodplains of the Northern Territory, Australia. Australian Biological Resources Study, Government Printers, Canberra, Australia.

Davies P.M., Bunn S.E. \& Hamilton S.K. (2008) Primary production in tropical streams and rivers. In: Tropical Stream Ecology (Ed. D. Dudgeon), Chapter 2, pp. 23-42. Elsevier London, U.K.

Davis A.M., Pusey B.J., Thorburn D.C., Dowe J.L., Morgan D.L. \& Burrows D. (2010) Riparian contributions to the diet of terapontid grunters (Pisces: Terapontidae) in wet-dry tropical rivers. Journal of Fish Biology, 76, 862-879.

Dostine P. \& Skeat A. (1993) Waterbird population and habitat monitoring project. OSS/ANPWS Internal Report 111, Supervising Scientist for the Alligator Rivers Region, Canberra, Australia.

Douglas M.M., Bunn S.E., Pidgeon R.J.W., Davies P.M., Barrow P., O’Connor R.A. \& Winning M. (2002). Weed management and the biodiversity and ecological processes of tropical wetlands. Report to the National Wetlands R and D Program, Environment Australia \& Land and Water Australia, Canberra, Australia.

Douglas M.M. \& O'Connor R.A. (2003) Effects of the exotic macrophyte, para grass (Urochloa mutica), on benthic and epiphytic macroinvertebrates of a tropical floodplain. Freshwater Biology, 48, 962-971.

Douglas M.M. \& O’Connor R.A. (2004) Weed invasion changes fuel characteristics: Para grass (Urochloa mutica (Forssk.) T.Q. Nguyen) on a tropical floodplain. Ecological Management and Restoration, 5, 143-145.

Douglas M.M., Bunn S.E. \& Davies P.M. (2005) River and wetland food webs in Australia's wetdry tropics: general principles and implications for management. Marine and Freshwater Research, 56, 329-32.

Dudgeon D. (1992) Endangered ecosystems: a review of the conservation status of tropical Asian rivers. Hydrobiologia, 248, 167-191.

Edwards A., Kennett R., Price O., Russell-Smith J., Spiers G. \& Woinarski J. (2003) Monitoring the impacts of fire regimes on vegetation in northern Australia: an example from Kakadu National Park. International Journal of Wildland Fire, 12, 427-440.

Ferdinands K., Beggs K. \& Whitehead P. (2005) Biodiversity and invasive grass species: multiple-use or monoculture? Wildlife Research, 32, 447-457.

Finlayson C.M., Bailey B.J., Freeland W.J. \& Fleming M. (1988) Wetlands of the Northern Territory. In: The Conservation of Australian Wetlands (Eds A.J. McComb and P.S. Lake), pp. 103-116. Surrey Beatty and Sons, Sydney, Australia.

Finlayson C.M., Bailey B.J. \& Cowie I.D. (1989) Macrophytic vegetation of the Magela floodplain, northern Australia. Research Report No. 5, Office of the Supervising Scientist, Canberra, Australia. 
Running title - Wet \& Dry contrasts in carbon resources on a tropical floodplain

Finlayson C.M., Cowie I.D. \& Bailey B.J. (1990a) Sediment seedbanks in grassland on the Magela creek floodplain, northern Australia. Aquatic Botany, 38, 163-176.

Finlayson C.M., Cowie I.D. \& Bailey B.J. (1990b) Characteristics of a seasonally flooded freshwater system in monsoonal Australia. In: Wetland ecology and management: case studies (Eds D.F. Whigham, R.E. Good \& J. Kvet), pp. 141-162. Kluwer Academic Publishers, Dordrecht, Netherlands.

Finlayson C.M. (1991) Production and major nutrient composition of three grass species on the Magela floodplain, Northern Territory, Australia. Aquatic Botany, 41, 263-280.

Finlayson C.M., Cowie I.D. \& Bailey B.J. (1993) Biomass and litter dynamics in a Melaleuca forest on a seasonally inundated floodplain in tropical, northern Australia. Wetlands Ecology and Management, 2, 177-188.

Finlayson C.M. (2005) Plant ecology of Australia's tropical floodplain wetlands: A review. Annals of Botany, 96, 541-555.

Forsberg B.R., Araujo-Lima C.A.R.M., Martinelli L.A., Victoria R.L. \& Bonassi J.A. (1993) Autotrophic carbon sources for fish of the central Amazon. Ecology, 74, 643-652.

Gardner S., Finlayson C.M. \& Pidgeon R.W.J. (2002) Description and literature review of the flora and vertebrate fauna of Magela Creek, Alligator Rivers region, northern Australia. Environmental Research Institute of the Supervising Scientist, 169, Darwin, Australia.

Gill A.M., Ryan P.G., Moore P.H.R. \& Gibson M. (2000) Fire regimes of world heritage Kakadu National Park. Austral Ecology, 25, 616-625.

Goncalves J.F., Franca J.S., Medeiros A.O., Rosa C.A. \& Callisto M. (2006) Leaf breakdown in a tropical stream. International Review of Hydrobiology, 91, 164-177.

Goulding M. (1980) 'The Fish and the Forest.' University of California Press, California USA.

Grace J., San Jose J., Meir P., Miranda H. \& Montes R.A. (2006) Productivity and carbon fluxes of tropical savannas. Journal of Biogeography, 33, 387-400.

Greenway M. (1994) Litter accession and accumulation in a Melaleuca quinquenervia wetland in south-east Queensland. Australian Journal of Marine and Freshwater Research, 45, 15091519.

Hamilton S.K. \& Lewis W.M. (1987) Causes of seasonality in the chemistry of a lake on the Orinoco River floodplain, Venezuela. Limnology and Oceanography, 32, 1277-1290.

Hamilton S.K., Lewis W.M. \& Sippel S.J. (1992) Energy sources for aquatic animals in the Orinoco River floodplain: evidence from stable isotopes. Oecologia, 89, 324-330.

Hamilton S.K. \& Gehrke P.C. (2005) Australia's tropical river systems: current scientific understanding and critical knowledge gaps for sustainable management. Marine and Freshwater Research, 56, 243-252.

Hart B.T. \& McGregor R.J. (1980) Limnological survey of eight billabongs in the Magela Creek Catchment, Northern Territory. Australian Journal of Marine and Freshwater Research, 31, 611-626.

Hart B. T., Ottaway E. M. \& Noller B. N. (1987a) Magela Creek system, northern Australia, I. 1982-83 wet-season water quality. Australian Journal of Marine and Freshwater Research, 38, 261-288.

Hart B. T., Ottaway E. M., \& Noller B. N. (1987b) Magela Creek system, northern Australia II. Material budget for the floodplain. Australian Journal of Marine and Freshwater Research, 38, $861-876$.

Houston D.L. \& Shine R. (1993) Sexual dimorphism and niche divergence: feeding habits of the arafura filesnake. Journal of Animal Ecology, 62, 737-749. 
Running title - Wet \& Dry contrasts in carbon resources on a tropical floodplain

Houston D. \& Shine R. (1994) Population demography of Arafura filesnakes (Serpentes: Acrochordidae) in tropical Australia. Journal of Herpetology, 28, 273-280.

Jacobsen D., Cressa C., Mathooko J.M. \& Dudgeon D. (2008) Macroinvertebrates: Composition, life histories and production. In: Tropical Stream Ecology (Ed. D. Dudgeon), pp. 66-106. Academic Press - Elsevier, Amsterdam, Netherlands.

Jackson S., Storrs M. \& Morrison J. (2005) Recognition of Aboriginal rights, interests and values in river research and management: perspectives from northern Australia. Journal of Ecological Management and Restoration, 6, 107-110.

Jenkins R.W.G. \& Forbes M.A. (1985) Seasonal variation in abundance and distribution of Crocodylus porosus in the tidal East Alligator River, Northern Australia. In: Biology of Australian Frogs and Reptiles (Eds G. Grigg, R. Shine and H. Ehmann), pp. 63-69. Surrey Beatty and Sons, Sydney, Australia.

Jepsen D.B. \& Winemiller K.O. (2002) Structure of tropical river food webs revealed by stable isotope ratios. Oikos, 96, 46-55.

Junk W.J., Bayley P.B. \& Sparks R.E. (1989) The flood pulse concept in river-floodplain systems. In: International large river symposium (Ed. D.P. Dodge) pp. 110-127. Fisheries and Aquatic Sciences Special Publication.

Junk W.J. \& Welcomme R.L. (1990) Floodplains. In: Wetlands and Shallow Continental Waterbodies (Ed. B.C. Patten), pp. 491-524. SPB Academic Publishing, The Hague, The Netherlands.

Junk W.J. (1993) Wetlands of tropical South America. In: Wetlands of the World I: Inventory, ecology and management (Eds. D.F. Whigham, D. Dykyjova \& S. Hejny), pp. 679-739. Kluwer Academic Publishers, Dordrecht, The Netherlands.

Junk W.J. (1997) Structure and function of the large central Amazonian River floodplains: Synthesis and discussion. In: The Central Amazon Basin: Ecology of a pulsing basin (Ed. W.J. Junk), pp. 455-473. Springer, Berlin, Germany.

Junk W.J. \& Piedade M.T. (1997) Plant life in the floodplain with special reference to herbaceous plants. In: The Central Amazon Basin: Ecology of a pulsing basin (Ed. W.J. Junk). pp. 147185. Springer, Berlin, Germany.

Junk W.J. \& Wantzen K.M. (2004) The flood pulse concept: new aspects, approaches and applications - an update. In: 2nd International symposium on the management of large rivers for fisheries (Eds. R.L. Welcomme \& T. Petr). FAO \& Mekong River Commission, Bangkok, Thailand.

Kirchman D.L. (1993) Leucine incorporation as a measure of biomass production by heterotrophic bacteria. In: Handbook of Methods in Aquatic Microbial Ecology (Eds. P.F. Kemp, B.F. Sherr, E.B. Sherr and J.J. Cole). Lewis Publishers, Boca Raton, Florida U.S.

Legler J.M. (1982) The ecology of freshwater turtles in the Alligator Rivers Region. Open file record 66, Supervising Scientist for the Alligator Rivers Region, Canberra, Australia.

Lewis W.M. (2008) Physical and chemical features of tropical flowing waters. In: Tropical Freshwater Ecology (Ed. D. Dudgeon), pp. 2-23. Academic Press, Amsterdam, Netherlands.

Lewis W.M., Hamilton S.K., Lasi M.A., Rodriguez M. \& Saunders J.F. (2000) Ecological determinism on the Orinoco Floodplain. Bioscience, 50, 681-692.

Lewis W.M., Hamilton S.K., Rodriguez M.A., Saunders J.F. \& Lasi M.A. (2001) Foodweb analysis of the Orinoco floodplain based on production estimates and stable isotope data. Journal of the North American Benthological Society, 20, 241-254. 
Running title - Wet \& Dry contrasts in carbon resources on a tropical floodplain

Madsen T. \& Shine R. (1996) Seasonal migration of predators and prey - A study of pythons and rats in tropical Australia. Ecology, 77, 149-156.

Marchant R. (1982) Seasonal variation in the macroinvertebrate fauna of billabongs along Magela Creek, Northern Territory. Australian Journal of Marine and Freshwater Research, 33, 329-342.

Martinelli L.A., Ballester M.V., Krusche A.V., Victoria R.L., deCamargo P.B., Bernades M \& Ometto J.P. (1999) Land-cover changes and delta C-13 composition of riverine particulate matter in the Piracicaba River basin (southeast region Brazil). Limnology and Oceanography, 44, 1826-1833.

McBride P. (1983) Diatom communities of the Mudginberri Corridor, Northern Territory, Australia: Their structure, annual succession, and responses to environmental change. $\mathrm{PhD}$ Thesis, Macquarie University, Sydney, Australia.

McClain M.E. \& Richey J.E. (1996) Regional-scale linkages of terrestrial and lotic ecosystems in the Amazon basin: a conceptual model for organic matter. Arch. Hydrobiologia Suppl., 113, 111-125.

McMahon T.A., Finlayson B.L., Haines A.T. \& Srikanthan R. (1991) Global Runoff: Continental Comparisons of Annual Flow and Peak Discharges. Catena Verlag, Cremlingen, Germany.

Morton S.R., Brennan K.G. \& Armstrong M.D. (1990a) Distribution and abundance of magpie geese, Anseranas semipalmata, in the Alligator Rivers region, Northern Territory. Australian Journal of Ecology, 15, 307-320.

Morton S.R., Brennan K.G. \& Armstrong M.D. (1990b) Distribution and abundance of ducks in the Alligator Rivers region, Northern Territory. Australian Wildlife Research, 17, 573-590.

Morton S.R., Brennan K.G. \& Armstrong M.D. (1993a) Distribution and abundance of brolgas and black-necked storks in the Alligator Rivers region, Northern Territory. EMU, 93, 88-92.

Morton S.R., Brennan K.G. \& Armstrong M.D. (1993b) Distribution and abundance of herons, egrets, ibises and spoonbills in the Alligator Rivers region, Northern Territory. Wildlife Research, 20, 23-43.

Naiman R.J. \& Decamps H. (1997) The ecology of interfaces: Riparian zones. Annual Review of Ecological Systematics, 28, 621-658.

Naiman R.J., Décamps H. \& McClain ME (2005) Riparia: Ecology, conservation and management of streamside communities. Elsevier Academic Press, Boston, USA.

Nakano S. \& Murakami M. (2001) Reciprocal subsidies: Dynamic interdependence between terrestrial and aquatic food webs. Proceedings of the National Academy of Sciences of the United States of America, 98, 166-170.

Odum H.T. (1957) Trophic structure and productivity of Silver Springs, Florida. Ecological Monographs, 27, 55-112.

Outridge P.M. (1988) Seasonal and spatial variations in benthic macroinvertebrate communities of Magela Creek, Northern Territory. Australian Journal of Marine and Freshwater Research, 39, 211-223.

Parks and Wildlife Service of the Northern Territory (2004) Management plan for Crocodylus porosus in the Northern Territory 2005-2010 (www.nt.gov.au/nreta/publications/wildlife/index).

Perga M-E., Arfi R. \& Gerdeaux D. (2005) Seasonal variations in fish ${ }^{13} \mathrm{C}$ and ${ }^{15} \mathrm{~N}$ in two West African reservoirs, Selingue and Manantali (Mali): modifications of trophic links in relation to water level. Isotopes Environmental Health Studies, 41, 109-123. 
Running title - Wet \& Dry contrasts in carbon resources on a tropical floodplain

Petheram C., McMahon T.A. \& Peel M.C. (2008) Flow characteristics of rivers in northern Australia: implications for development. Journal of Hydrology, 357, 93-111.

Piedade M.T.F., Junk W.J. \& Long S.P. (1991) The productivity of the $\mathrm{C}_{4}$ grass Echinochloa polystachya on the Amazon floodplain. Ecology, 72, 1456-1463.

Salick J., Herrera R. \& Jordan C.F. (1983) Termitaria: nutrient patchiness in nutrient-deficient rain forests. Biotropica, 15, 1-7.

Shine R. (1986) Ecology of a low-energy specialist: food habits and reproductive biology of the arafura filesnake (Acrochordidae). Copeia, 1986, 424-437.

Stout J. (1980) Leaf decomposition rates in Costa Rican lowland tropical rainforest streams. Biotropica, 12, 264-272.

Stein J.L., Stein J.A. \& Nix H.A. (2002) Spatial analysis of anthropogenic river disturbance at regional and continental scales: identifying the wild rivers of Australia. Landscape and Urban Planning, 60, 1-25.

Strayer D.L. \& Findlay S.E.G. (2010) Ecology of freshwater shore zones. Aquatic Sciences, 72 , 127-163.

Thomas P.A., Davies S.H.R. \& Hart B.T. (1981) Transport of trace metals in the Magela Creek system, Northern Territory: III Billabong sediments. Technical Memorandum 3. Supervising Scientist for the Alligator Rivers Region. Australian Government Printing Service, Canberra, Australia.

Thorp J.H. \& Delong M.D. (1994) The riverine productivity model: an heuristic view of carbon sources and organic processing in large river ecosystems. Oikos, 70, 305-308.

Tockner K., Malard F. \& Ward J.V. (2000) An extension of the flood pulse concept. Hydrological Processes, 14, 2861-2883.

Tockner K., Lorang M.S. \& Stanford J.A. (2010) River flood plains are model ecosystems to test general hydrogeomorphic and ecological concepts. River Research and Applications, 26, 7686.

Tockner K., Pusch M., Borchardt D. \& Lorang M.S. (2010) Multiple stressors in coupled riverfloodplain ecosystems. Freshwater Biology, 55 (Suppl. 1), 135-151.

Walker T.D. \& Tyler P.A. (1983) Algal populations and phytoplanktonic productivity in billabongs of the Alligator Rivers Region. In: Environmental protection in the Alligator Rivers Region: A scientific workshop. Vol 1, Jabiru 17-20 May 1983, Supervising Scientist for the Alligator Rivers Region, Canberra, Australia.

Wasson R.J. (1992) (Ed.) Modern sedimentation and late Quaternary evolution of the Magela Creek Plain. Supervising Scientist for Alligator Rivers Region Research Report 6, Australian Government Publishing Service, Canberra, Australia.

Ward J.V. (1998) River landscapes: biodiversity patterns, disturbance regimes and aquatic conservation. Biological Conservation, 83, 269-278.

Webb G.J.W., Messel H., Crawford J. \& Yerbury M.J. (1978) Growth rates of Crocodylus porosus (Reptilia: Crocodilia) from Arnhem Land, North Australia. Australian Wildlife Research, 5, 385-399.

Webb G.J., Manolis S.C. \& Sack G.C. (1983) Crocodylus johnstoni and C. porosus coexisting in a tidal river. Australian Wildlife Research, 10, 639-650.

Williams A.R. (1979) Vegetation and stream pattern as indicators of water movement on the Magela floodplain, Northern Territory. Australian Journal of Ecology, 4, 239-247.

Winemiller K.O. \& Jepsen D.B. (1998) Effects of seasonality and fish movement on tropical river food webs. Journal of Fish Biology, 53, 267-296. 
Winemiller K.O. (1996) Factors driving spatial and temporal variation in aquatic floodplain food webs. In: Food webs: Integration of patterns and dynamics (Eds. G.A. Polis \& K.O. Winemiller), pp. 298-312. Chapman Hall, New York, USA.

Winemiller K.O. (2004) Floodplain river food webs: Generalisations and implications for fisheries management. In: 2nd International symposium on the management of large rivers for fisheries (Eds. R.L. Welcomme \& T. Petr). FAO \& Mekong River Commission, Bangkok, Thailand.

Wurm P.A.S. (1998) A surplus of seeds: high rates of post-dispersal seed predation in a flooded grassland in monsoonal Australia. Australian Journal of Ecology, 23, 385-392.

Zeug S.C. \& Winemiller K.O. (2008) Evidence supporting the importance of terrestrial carbon in a large-river food web. Ecology, 89, 1733-1743. 
Running title - Wet \& Dry contrasts in carbon resources on a tropical floodplain

\section{$\underline{\text { Tables }}$}

Table 1: Estimates of the contribution of major plant and animal functional groups to carbon resources on the Magela Creek floodplain, based on biomass data synthesized in this article. Estimates are for annual biomass, unless otherwise specified.

\begin{tabular}{|c|c|c|}
\hline Source & Carbon $\left(\mathrm{kg} \mathrm{ha}^{-1}\right)$ & Reference \\
\hline Detritus & $7938-12826$ & $\begin{array}{l}\text { Finlayson, 1991; Finlayson et al., 1993; Douglas \& } \\
\text { O’Connor, } 2004\end{array}$ \\
\hline Bacteria & $0.35-5.4$ (production) & Castillo, 2003 \\
\hline Trees $^{1}$ & $21000-22500$ & Finlayson et al., 1993 \\
\hline Litterfall & $3500-3750$ & Finlayson et al., 1993 \\
\hline Aquatic grasses $^{2}$ & $\begin{array}{l}7590-14573 \text { (wet season) } \\
1822-3497 \text { (dry season) }\end{array}$ & Finlayson, 1991; Douglas \& O’Connor, 2004 \\
\hline \multicolumn{3}{|l|}{$\operatorname{Algae}^{3}$} \\
\hline Phytoplankton (billabongs) & $\begin{array}{l}180 \text { (dry season) } \\
400 \text { (wet season) }\end{array}$ & Hart \& MacGregor. 1980 \\
\hline Diatoms (epiphytes) & 850 (wet season) & McBride, 1983 \\
\hline Macroinvertebrates & $6-60$ & Outridge, 1988 \\
\hline Fish & $9-22$ (dry season) & Bishop et al. ,1987; Bishop et al., 1990 \\
\hline Turtles & 1.6 & Legler, 1982 \\
\hline File snakes & 0.5 & Shine, 1986; Houston \& Shine, 1994 \\
\hline Water birds & $\begin{array}{l}0.55-1.7 \text { (wet season) } \\
3.7-11.8 \text { (dry season) }\end{array}$ & Dostine \& Skeat, 1993; Morton et al., 1990ab, 1993 \\
\hline Crocodiles & $0.4-1.7$ & Webb et al., 1984; Jenkins \& Forbes, 1985. \\
\hline
\end{tabular}

${ }^{1}$ most carbon in tree biomass is locked up for decades, released as litterfall.

${ }^{2}$ aquatic grasses include Hymenachne acutigluma, Urochloa mutica, Pseudorhaphis spinescens and Oryza meridionalis.

Table 2: Water quality for flood event, first flow and main wet season on Magela Creek 1982-3 wet season (from Hart et al., 1987a).

\begin{tabular}{lcccl}
\hline & $\begin{array}{c}\text { Flood } \\
\text { event }^{\mathrm{a}}\end{array}$ & First flow $^{\mathbf{b}}$ & Wet season & $\begin{array}{l}\text { Total for } \\
\text { catchment }\end{array}$ \\
\hline $\mathrm{pH}$ & $5.2(5.2-5.3)$ & $5.6(5.4-5.7)$ & $5.2(4.8-5.8)$ & \\
$\mathrm{TSS}\left(\mathrm{mg} \mathrm{L}^{-1}\right)$ & $12(6-28)$ & $3(<0.6-8.4)$ & $13(3.8-59)$ & $39 \mathrm{~kg} \mathrm{ha}^{-1} \mathrm{yr}^{-1}$ \\
$\mathrm{TDS}\left(\mathrm{mg} \mathrm{L}^{1}\right)$ & & & & $21 \mathrm{~kg} \mathrm{ha}^{-1} \mathrm{yr}^{-1}$ \\
$\mathrm{EC}\left(\mu \mathrm{S} \mathrm{cm}^{-1}\right) *$ & $8.4(7.3-12)$ & $15(14-16)$ & $10(5.4-17)$ & \\
$\mathrm{Na}\left(\mathrm{mg} \mathrm{L}^{-1}\right)$ & $0.8(0.7-0.9)$ & $1.3(1-1.6)$ & $0.9(0.6-1.1)$ & $2.5 \mathrm{~kg} \mathrm{ha}^{-1} \mathrm{yr}^{-1}$ \\
$\mathrm{~K}\left(\mathrm{mg} \mathrm{L}^{-1}\right)$ & $0.3(0.2-0.5)$ & $0.8(0.7-1)$ & $0.3(0.2-0.6)$ & $0.9 \mathrm{~kg} \mathrm{ha}^{-1} \mathrm{yr}^{-1}$ \\
$\mathrm{Ca}\left(\mathrm{mg} \mathrm{L}^{-1}\right)$ & $0.2(0.1-0.3)$ & $0.4(0.2-0.8)$ & $0.3(<0.1-1.5)$ & $0.7 \mathrm{~kg} \mathrm{ha}^{-1} \mathrm{yr}^{-1}$ \\
$\mathrm{Cl}\left(\mathrm{mg} \mathrm{L}^{-1}\right)$ & $1.4(0.8-2)$ & $2(2-3)$ & $1.7(<1-3)$ & $4.3 \mathrm{~kg} \mathrm{ha}^{-1} \mathrm{yr}^{-1}$ \\
$\mathrm{Total} \mathrm{P}\left(\mu \mathrm{g} \mathrm{L} \mathrm{L}^{-1}\right)$ & $7(5-13)$ & $15(<10-30)$ & $6(<10-30)$ & $16 \mathrm{~g} \mathrm{ha}^{-1} \mathrm{yr}^{-1}$ \\
$\mathrm{NO}_{3}\left(\mu \mathrm{g} \mathrm{N} \mathrm{l}^{-1}\right)$ & $30(20-30)$ & $200(100-2700)$ & $43(<10-79)$ & $90 \mathrm{~g} \mathrm{ha}^{-1} \mathrm{yr}^{-1}$ \\
$\mathrm{NH}_{4}\left(\mu \mathrm{g} \mathrm{N} \mathrm{L}^{-1}\right)$ & $<10(<10)$ & $6(<10-20)$ & $5(<10)$ & \\
\hline
\end{tabular}

* at $25^{\circ} \mathrm{C} ;{ }^{\text {a }}$ mean of five flood events (range); ${ }^{\mathrm{b}}$ mean (range), $\mathrm{n}=5-21 ;{ }^{\mathrm{c}}$ mean (range), $\mathrm{n}=45$. 
Running title - Wet \& Dry contrasts in carbon resources on a tropical floodplain

Table 3: Wet and dry season contrasts of water bird densities (based on aerial surveys) and biomass (based on average bird weights) on Magela Creek floodplain in 1990 and 1980.

\begin{tabular}{|c|c|c|c|c|c|c|c|c|}
\hline \multirow[t]{2}{*}{ Species } & \multicolumn{2}{|c|}{$\begin{array}{l}\text { Dry season abundance } \\
\left(\text { no. } \mathbf{k m}^{-2}\right)\end{array}$} & \multicolumn{2}{|c|}{$\begin{array}{l}\text { Wet season abundance } \\
\left(\text { no. } \mathbf{k m}^{-2}\right)\end{array}$} & \multicolumn{2}{|c|}{$\begin{array}{l}\text { Dry season } \\
\text { biomass }\left(\mathrm{kg} \mathrm{ha}^{-1}\right)\end{array}$} & \multicolumn{2}{|c|}{$\begin{array}{l}\text { Wet season } \\
\text { biomass }\left(\mathrm{kg} \mathrm{ha}^{-1}\right)\end{array}$} \\
\hline & $1990^{7}$ & $1980-4^{8}$ & 1990 & $1980-4$ & 1990 & $1980-4$ & 1990 & $1980-4$ \\
\hline Magpie geese & $237 \pm 31$ & 691 & $33 \pm 45$ & 106 & 5.82 & 17.25 & 0.85 & 2.60 \\
\hline Black ducks & $7 \pm 6$ & 79 & $0.9 \pm 2$ & 10 & 0.07 & 0.87 & 0.09 & 0.10 \\
\hline Burdekin ducks & $4.2 \pm 3$ & 42 & $0.5 \pm 0.5$ & 2.6 & 0.04 & 0.38 & 0.002 & 0.02 \\
\hline Grey teal & $2.2 \pm 2$ & 58 & $1 \pm 2$ & 2.6 & 0.02 & 0.38 & 0.006 & 0.02 \\
\hline Whistling ducks ${ }^{1}$ & $57 \pm 38$ & 159 & $1.9 \pm 2.2$ & 5.3 & 0.43 & 1.19 & 0.014 & 0.04 \\
\hline Egrets $^{2}$ & $66.2 \pm 12$ & 132 & $20 \pm 17$ & 44 & 0.26 & 0.53 & 0.08 & 0.18 \\
\hline Herons $^{3}$ & $24 \pm 14$ & 111 & $1.7 \pm 5$ & 1.3 & 0.13 & 0.61 & 0.009 & 0.007 \\
\hline Spoonbills ${ }^{4}$ & $2.5 \pm 2$ & 42 & $0.2 \pm 1$ & 0.2 & 0.02 & 0.33 & 0.002 & 0.002 \\
\hline Jabirus & $0.2 \pm 0.3$ & 1.5 & $0.2 \pm 0.3$ & 0.6 & 0.008 & 0.06 & 0.008 & 0.02 \\
\hline Brolgas & $7.6 \pm 3$ & 9.5 & $2 \pm 2$ & 6.3 & 0.49 & 0.62 & 0.01 & 0.40 \\
\hline Ibises $^{5}$ & $47.2 \pm 20$ & 297 & $1.2 \pm 3$ & 3.6 & 0.23 & 1.48 & 0.005 & 0.02 \\
\hline Pelicans & $0.2 \pm 0.5$ & & 0 & & 0.02 & & 0 & \\
\hline Cormorants ${ }^{6}$ & $0.2 \pm 1$ & & $0.2 \pm 1$ & & 0.001 & & 0.001 & \\
\hline Totals & 455.5 & 1622 & 61.7 & 182.5 & 7.53 & 23.70 & 1.12 & 3.40 \\
\hline
\end{tabular}

\section{$\underline{\text { Figure Captions }}$}

Figure 1: Location of the Magela Creek floodplain within Kakadu National Park, east of Darwin in the wet/dry tropics of Northern Australia.

Figure 2: Magela Creek wet season (October to April) (a) rainfall (mm) and (b) stream flow volume (ML) from 1972 to 2006 (5-year moving averages shown).

Figure 3: a) Dry season and b) Wet season fluxes of carbon and generalised food web components for the Magela Creek floodplain. Size of boxes give the relative contribution to biomass of each group and relative size of arrow represent dominant pathways. Boxes with broken lines indicates lack of data. 